\title{
\$POTTED SANDPIPERS AS POSSIBLE INDICATORS OF MERCURY CONTAMINATION OF RIVERS
}

by Kees Vermeer, Canadian Wildlife Service, Edmonton

Islands in the North Saskatchewan iver above and below Edmonton were hvestigated during the summer of 970 for the purpose of finding a suitble species of aquatic or shore bird to erve as an indicator of the mercury ontamination of that river. Although o mmon Goldeneyes, which were mong the four most common species bserved, would have been preferred as dicators because of their known diet f aquatic invertebrates (Kortright, he ducks, geese and swans of North merica, Stockpole Co., Harrisburg nd Wildl. Mgt. Inst., Washington, 962), no nests of this species were und. Of all the aquatic and shore irds observed, Spotted Sandpipers Actitis macularia) were most freuently seen and their nests were asily found. Observations made elsehere in North America have shown hat Spotted Sandpipers feed chiefly $n$ aquatic and terrestrial insects and ccasionally on small fish (Bent, Life istories of North American shore irds, Part I, U.S. Natl. Mus. Bull. 42, New York, 1927), but the proortions of the two groups of insects one another within their diet apears to be unknown. For that reason 6 specimens were collected along the North Saskatchewan River during the rst weeks of July and August, 1970. he project was started during midune so no data on food habits are vailable earlier than that date. hirty-one of the 36 stomachs anavzed contained food items (Table I). was interesting to find that terresrial insects occurred much more freuently than aquatic insects, with veevils constituting the most imortant food item of the sandpipers' iet. Of the three most frequently ccurring insect families, Curculiontae and Hydropsychidae occurred nore frequently in July than August, while the Formicidae showed the oppoite trend.
Table 1: Percentage occurrence of insect families in stomachs of 31 Spotted Sandpipers collected along the North Saskatchewan River, Alberta, in 1970.

\begin{tabular}{|c|c|c|c|}
\hline & $\begin{array}{l}\text { First } \\
\text { week } \\
\text { f July }\end{array}$ & $\begin{array}{l}\text { First } \\
\text { week } \\
\text { of Aug. }\end{array}$ & $\begin{array}{l}\text { July } \\
\text { and } \\
\text { Aug. }\end{array}$ \\
\hline & 15 & 16 & 31 \\
\hline \multicolumn{4}{|l|}{ Coleoptera } \\
\hline Curculionidae & 94 & 47 & 71 \\
\hline Haliplidae $\dagger$ & 25 & 40 & 32 \\
\hline Carabidae & 31 & 27 & 29 \\
\hline Scarabaeidae & 13 & 7 & 10 \\
\hline Dytiscidae $\dagger$ & 13 & 0 & 6 \\
\hline Cerambycidae & 6 & 0 & 3 \\
\hline Tenebrionidae & 6 & 0 & 3 \\
\hline \multicolumn{4}{|l|}{ Hymenoptera } \\
\hline Formicidae & 44 & 80 & 61 \\
\hline Vespidae & 0 & 7 & 3 \\
\hline Ichneumonidae & 0 & 7 & 3 \\
\hline Teuthrinidae & 6 & 0 & 3 \\
\hline \multicolumn{4}{|l|}{ Trichoptera } \\
\hline Hydropsychidae* & 56 & 27 & 42 \\
\hline \multicolumn{4}{|l|}{ Hemiptera } \\
\hline Cicadellidae & 25 & 13 & 19 \\
\hline Pentatomidae & 0 & 7 & 3 \\
\hline Lygaeidae & 0 & 7 & 3 \\
\hline \multicolumn{4}{|l|}{ Plecoptera } \\
\hline Perlidae* & 31 & 0 & 16 \\
\hline \multicolumn{4}{|l|}{ Diptera } \\
\hline Dolichopodidaet & 6 & 27 & 16 \\
\hline Tachinidae & 6 & 13 & 10 \\
\hline Empididae* or & 13 & 0 & 6 \\
\hline Culicidae & 13 & 0 & 6 \\
\hline Sciomyzidae* & 0 & 7 & 3 \\
\hline Stratiomyidae* & 0 & 7 & 3 \\
\hline Chironomidae* & 6 & 0 & 3 \\
\hline Sarcophagidae & 6 & 0 & 3 \\
\hline \multicolumn{4}{|l|}{ Odonata } \\
\hline Libellulidae* & 6 & 13 & 10 \\
\hline Lestidae* & 6 & 7 & 6 \\
\hline \multicolumn{4}{|l|}{ Orthoptera } \\
\hline Acrididae & 13 & 7 & 10 \\
\hline
\end{tabular}

$\dagger$ aquatic adult

* aquatic larva

shore insect 
One egg from each of 33 sandpiper nests was collected on river islands in June and July. Fourteen eggs were from upstream of Edmonton, between Huggett and Devon, and 19 eggs were collected downstream from Edmonton between Vinca Bridge and Duvernay. The eggs were analyzed for residues of mercury in order to determine whether they could be used as indicators of mercury contamination sources located at Edmonton and/or downstream from that city. The mean and 05 per cent confidence interval of mercury residue levels in the 14 sandpiper eggs collected upstream from Edmonton were $0.09 \pm 0.03 \mathrm{ppm}$, as compared to $0.28 \pm 0.06 \mathrm{ppm}$ in the 19 sandpiper eggs collected downstream from tha city. The difference between thos levels is statistically significant an suggests a source of mercury contami nation at and/or downstream of Ed nonton. As the sandpiper's diet con sists of both terrestrial and aquati insects, the source of mercury pollu tion could not be further identified.

Although the Spotted Sandpipe does not appear to be a suitable ind cator of mercury contamination of th North Saskatchewan River, we ol tained a little more knowledge of $i$ food habits and its occurrence alon the river. The authors thank $\mathrm{Mr}$. I Kavanagh for his assistance with th identification of insects.

\section{RECENT BIRD NOTES OF INTEREST FOR CHURCHILL, MANITOBA}

by Ron Pittaway, 79 College Avenue, Ottawa, Ontario and Robert W. Nero, 546 Coventry Road, Winnipeg, Manitoba

Shortly after the publication of any local annotated list of birds a number of unusual birds are sure to appear in that locality. The following records include seven species not previously reported for Churchill, three of which are first records for Manitoba. Nearly all were obtained at Churchill at the time the recently published Birds of the Churchill region, Manitoba (Jehl and Smith, 1970) was in the hands of the printer. Judging by these additions, the Churchill region still offers ornithological surprises.

The senior author, who was at Churchill studying birds from May 5 to July 23, 1970, looks upon Churchill as the Point Pelee of the north. Birders who have spent any time at Point Pelee National Park on Lake Ontario will appreciate this remark, for the Point Pelee area attracts swarms of migrant birds in both spring and fall. Churchill is now a Mecca for birders who wish to see a lot of birds that are difficult to find anywhere in southern Canada. It also offers a chance to see birds that are rare on the continent.
Thanks are due the following pe sons for the use of their records for supporting observations: Dunc: R. Mackenzie, Churchill; Paul Mirs and others in his party, Queen's Ur versity, Kingston, Ontario; Dr. I Newton, Nature Conservancy, Edi burgh Scotland; Jerry Rosenbar Skokie, Illinois; and Mrs. Blanc Smith and Irwin H. Smith, Church.

\section{SPECIES LIST}

Harlequin Duck Histrionicus histrionicus

A male in breeding plumage $w$ observed by Pittaway and I. Newt on the Churchill River at Cape Mer July 11, 1970. The bird was stud closely for half an hour with binor lars and a Bausch and Lomb $15 \mathrm{x}$ zoom-telescope, at times as close 200 feet. It was observed swimmi in flight, and sitting on exposed roc It was last seen by Pittaway on $J$ 14.

This is the first record for Church As pointed out by Manning (19) 